Abstract

\title{
Microbiota Composition Affects Life History Traits in Drosophila Species ${ }^{\dagger}$
}

\author{
Mirjana Beribaka ${ }^{1}$, Mihailo Jelić ${ }^{2}$, Cvijeta Lazić ${ }^{1}$ and Marina Stamenković-Radak ${ }^{2}$ \\ 1 Faculty of Technology Zvornik, University of East Sarajevo, Karakaj 34A, 75400 Zvornik, Bosnia and Herze- \\ govina \\ 2 Faculty of Biology, University of Belgrade, Studentski trg 16, 11000 Belgrade, Serbia \\ * Correspondence: mirjana.beribaka@tfzv.ues.rs.ba \\ + Presented at the 1st International Electronic Conference on Entomology (IECE 2021), 1-15 July 2021; \\ Available online: https://iece.sciforum.net/.
}

Citation: Beribaka, M.; Jelić, M.; Lazić, C.; Stamenković-Radak, M. Microbiota Composition Affects Life History Traits in Drosophila Species, in Proceedings of the 1st International Electronic Conference on Entomology, 1-15 July 2021, MDPI: Basel, Switzerland, doi:10.3390/IECE10511

Published: 1 July 2021

Publisher's Note: MDPI stays neutral with regard to jurisdictional claims in published maps and institutional affiliations.

Copyright: (C) 2021 by the authors. Submitted for possible open access publication under the terms and conditions of the Creative Commons Attribution (CC BY) license (http://creativecommons.org/licenses /by/4.0/).

\begin{abstract}
Life history traits determine the survival of species and their reproduction and as such, they represent the main components of fitness. There are numerous factors that can affect life history traits, both external and internal. We investigated the influence of the composition of microbiota on two life history traits, egg to adult viability and developmental time, in two species, Drosophila melanogaster and Drosophila subobscura grown in laboratory on standard (over 50 generations) and lead (II) acetate $\left(\mathrm{Pb}\left(\mathrm{CH}_{3} \mathrm{COO}\right)_{2}\right)$ saturated substrates (over 30 generations). The composition of microbiota in larvae and adults was determined by sequencing (NGS) of the V3-V4 variable regions of the $16 S$ rRNA gene. The relationship between changes in the composition of microbiota and studied traits was analysed. The substrate $\times$ species interaction shows a significant effect on both fitness components. In D. subobscura, developmental time shows a higher tendency of slowing down on lead saturated substrate compared to D. melanogaster. Reduced viability in D. melanogaster could be a cost of faster development and presence of endosymbiotic bacteria (Wolbachia). Microbiota diversity indicates that the high prevalence of genus Komagataeibacter could be a key to better tolerance of lead pollution in D. subobscura. The study of additional factors that may affect the composition of the microbiota, and consequently the potential trade-offs among different life history traits is of great importance in evolutionary research.
\end{abstract}

Keywords: Drosophila melanogaster; Drosophila subobscura; egg to adult viability; developmental time; microbiota composition 